\title{
Morphological Variation of Six Pigmented Rice Local Varieties Grown in Organic Rice Field in Sengguruh Village, Kepanjen District, Malang Regency
}

\author{
Shinta $^{1}$, Serafinah Indriyani $^{1 *}$, Endang Arisoesilaningsih $^{1}$ \\ ${ }^{1}$ Biology Department, Faculty of Mathematics and Natural Sciences, University of Brawijaya Malang
}

\begin{abstract}
Indonesia is the third richest country for pigmented rice source such as Wojalaka black rice of East
\end{abstract} Nusa Tenggara (NTT), Manggarai of NTT, Toraja of South Sulawesi, Cempo Ireng of Central Java and red rice of Aek Sibundong (leading variety) and Baubau of Southeast Sulawesi. However, the morphological character of pigmented rice in Indonesia is less reported. The objective of research was to compare the morphological variation of root, stem, leaf, panicle, floret and the colour of milk mature grain and mature grain by observing the vegetative and generative parts of six local rice varieties. Research had been conducted from February 2012 to February 2014 in Sengguruh Village, Kepanjen District, Malang Regency. This study type was quasi-experiment with eleven replications. Group Random Design was used. The observation was given upon vegetative, reproductive and maturity phases as groups. Independent variables in this study were six rice varieties, while the dependent variable was morphological variation (root, stem, leaf, panicle, floret, milk mature grain and mature grain). The analysis of multivariate data in cluster and biplot was carried out with PAST. The result of the study indicated that there was morphological difference on stem, leaf, panicle, floret, milk mature grain and mature grain. The colour of the stem in Aek Sibundong variety was purple, while that of other varieties was green. Toraja and Manggarai varieties had the highest height with $163-168 \mathrm{~cm}$, followed by Cempo Ireng with $139 \mathrm{~cm}$, Wojalaka and Baubau with 110-112 cm. Aek Sibundong Variety had the lowest height with $99 \mathrm{~cm}$. Aek Sibundong and Wojalaka varieties had 6-7 internodes which were the greatest number of internode, while other varieties only had 4-5 internodes. Some varieties, such as Aek Sibundong, Wojalaka and Baubau had short and small leaf. The leaflet angle of Aek Sibundong and Baubau were $14^{\circ}$ and it might be said as upright, while that of Wojalaka was $43^{\circ}$ or moderate. Cempo Ireng, Manggarai and Toraja had its $63-88^{\circ}$ of the leaflet angle or it was said as flat. Cempo Ireng and Wojalaka were included into Rice Indica Group while Toraja, Manggarai, Cempo Ireng and Baubau belonged to Rice Javanica Group. There were two morphological groups. Group 1 included Toraja, Manggarai and Cempo Ireng, while Group 2 consisted of Aek Sibundong, Baubau and Wojalaka.

Keywords: morphological variation, pigmented local rice, vegetative and generative

\section{INTRODUCTION}

Indonesia is the third richest country for its pigmented rice source $(7.2 \%)$, after China $(62 \%)$, Sri Lanka (8.6\%), India (5.1\%), Philippine (4.3\%),

*Corresponding author:

Serafinah Indriyani

Biology Department, Faculty of Mathematics and Natural

Sciences, University of Brawijaya, Malang

E-mail: s.indriyani@ub.ac.id
Bangladesh (4.1\%), and other countries such as Malaysia, Thailand and Myanmar with only minor percentage [1]. Distinguishing pigmented rice is based on a colour covering the outer layer of seed. Thus, the brownish red rice is called red rice while the purplish is called black rice. This pigment remains in the aleurone layer of rice seed, and it is recognized as the mix of anthocyanin compounds [2]. In Indonesia, the pigmented rice (brown, red or black) is less studied compared to white rice. Therefore, the 
information of pigmented rice as the functional food is very limited [3]. White rice is the mostconsumed rice but pigmented rice is also considered as useful for the health in term of taste, nutrient and anthocyanin content [4].

Some results of previous research have indicated that pigmented rice contains phenolic compound as the main active component of antioxidant $[2,5,6]$. Indeed, the benefit for health from anthocyanin extract of pigmented rice can prevent the growth of liver cancer cells [7]. The compounds isolated from pigmented rice (anthocyanin, cyanidin-3-glucoside, pelargonidin3 -glucoside) show the presence of aldose which is important for diabetes prevention [2]. It has been reported that a diet containing black rice extract with anthocyanin (31.3 g / $100 \mathrm{~g})$ can reduce cholesterol rate, LDL cholesterol and triacylglycerol concentration in the mice's plasma [8]. In addition, pigmented rice has low glycemic index, and it is recommended by WHO (World Health Organization) for global health programs [9]. Antioxidant activities in pigmented rice have been reported by [10-13]. They have stated that black and red rice are not only the main source of carbohydrate but also supplying the higher level of iron, zinc, calcium, copper, protein, betacarotene, antioxidant and manganese as the essential source of vitamin and mineral.

The productivity of pigmented rice is still low, and the availability in the market is very limited, and, the price is relative expensive [14]. Pigmented rice is not yet known as the primary food and as a herb for Indonesian people. The cultivation of pigmented rice is still challenged because the plant is easily collapsed and infected by natural pests such as bird and mouse. Therefore, the local farmers are not familiar and less willing to cultivate pigmented rice. Consequently, one of biological essences may be extinct in the immediate future [15]

Plant morphologies, such as the form and structure of plant organs, are used as the main base to classify the plant or as a tool to understand the adaptation of plant to the environment. Besides, the morphologies of certain plants are very influential to the rice productivity. The relationship of plant morphologies and productivity has led to the idea of creating an ideal type (idiotype) of plant [16, 17].
Morphological characters of pigmented rice in Indonesia are less reported. Any publications and descriptions are still confined to Cempo Ireng black rice and Aek Sibundong red rice. The leading capacities of Aek Sibundong includes productivity of 6-8 tons.ha-1, Shortage (110-120 days), resistance to wereng coklat (brown planthopper) biotype 1, 2, and 3 and also resistance to bacteria-induced leaf blight Strain IV, and it has a delicious taste with smooth texture meal [18]. The conservation of rice through cultivation still needs fundamental information about the reliable morphology. The morphology of pigmented rice is influenced by season, soil, water and climate. Therefore, the conservation by planting local pigmented rice must consider the cultivation of organic farming. Through organic farming, the yield of rice will support and develop food security, agroecosystem health, biodiversity, biological cycle and soil biological activity [19]. Pigmented rice varieties have been cultivated in Indonesia. Some are cultivated in an organic way in Malang District. They are black rice Wojalaka of East Nusa Tenggara (NTT), Manggarai of NTT, and Toraja in South Sulawesi; Cempo Ireng of Central Java and Aek Sibundong red rice (the leading variety) and Baubau of Southeast Sulawesi.

The objective of research was to compare the morphological variation of root, stem, leaf, panicle, floret and the colour of milk mature grain and mature grain by observing the vegetative and generative parts of six local rice varieties.

\section{MATERIALS AND METHODS}

The study had been conducted from February 2012 to February 2014 in Sengguruh Village, Kepanjen District, Malang Regency. The type was quasi-experiment with eleven replications. Group Random Design was used. The observation was given upon vegetative phase, reproductive phase and maturity phase as group. Independent variables were six rice varieties, while dependent variable was morphological variation (root, stem, leaf, panicle, floret, milk mature grain and mature grain).

Six pigmented rice varieties were seen in this study, namely Wojalaka (NTT), Manggarai of 
NTT, Toraja of South Sulawesi, Cempo Ireng of Central Java and Baubau red rice of Southeast Sulawesi. Aek Sibundong represented a crossbred (a leading commodity) used as a comparator. The seed was obtained from farmers in each region. The planting of rice included several activities: 1) Seeds were selected by sorting in order to achieve the uniformity (similar colour and size) and by submerging it into plain water for 24 hours, and after that, the seedling began. 2)The seedling of each pigmented rice variety was conducted in the $70 \mathrm{~cm}$ diameter pot. If the age of seed reached 25 days, the seedling was moved to organic field. 3) The land was prepared by mixing soil, sand and compost with the ratio of $5: 10: 1$. It was then positioned in the phytoremediation pool filled with kangkung (water spinach) by $5 \times 5 \mathrm{~cm}^{2}$ width. 4) The seed had to be healthy determined by the characters of higher, big and upright leaf. The planting was firstly begun in a narrow plot, with three seeds in one point with $25 \mathrm{~cm}$ interval. The planting was then moved to an organic field. 5) The fertilization used LMO (Local Micro Organism) and compost. The observation of morphological characters of six pigmented rice local varieties was conducted in three phases, namely vegetative II (Stage 3), reproductive (Stage 4, 5, and 6) and maturity phases (Stage 7 and 8). The observation on vegetative II stage concerned with stem color, leaf sheet color, leaf's maximum length and width, ligule's colour and length, leaf sheath color, leaf neck color, and trichome's variation and distribution in the adaxial and abaxial surfaces of the leaf. The observation of the reproductive stage considered plant height, stem diameter, angle, leaflet's length and width, panicle tip color, floret's color, length and width, and the presence of the tail in the distal part of the floret. The observed maturity phase involved the colour of milk mature grain and mature grain, the number and length of stem internode, and the presence of the tail at distal part of the grain. A color chart described the observation of color.

\section{Data Analysis}

The data of morphological variation were tabulated through MS Excel 2007 for windows. The descriptive data analysis was used to determine the average rate and the deviation standard of each variable. Data were analyzed by ANOVA at a cut off value of $\alpha$ of 0.05 . It was followed by HSD Tukey Test facilitated by SPSS 16.0. The analysis of multivariate data in cluster and biplot was carried out with Paleontological Statistics (PAST) [20].

\section{RESULTS AND DISCUSSION}

\section{Root Length}

The root of rice is classified into fibrous root. The result indicated a significant difference between Wojalaka whose short root was $16.5 \mathrm{~cm}$ and other varieties of Toraja, Manggarai, Cempo Ireng, Baubau and Aek Sibundong whose long root was 21-25 cm (Figure 1). Deep, thick, and health rooting which grasps land more widely and vigorously can hold against collapse, facilitated the absorption water and dry matter in more efficient way, especially at grain filling stadia [36]. Wider root spreading in the soil may reduce root resistance against the absorption of soil water [37]. Rice rooting relates closely with the tolerance of the plant to the drought [37]. The role of root in the soil water absorption during the growth might determine the smoothness of the photosynthesis process in producing rice grain. Rain-based field in a dry season depended greatly on the root because the absorption of soil water would always rely on the ability of root to penetrate the deeper layer of the soil.

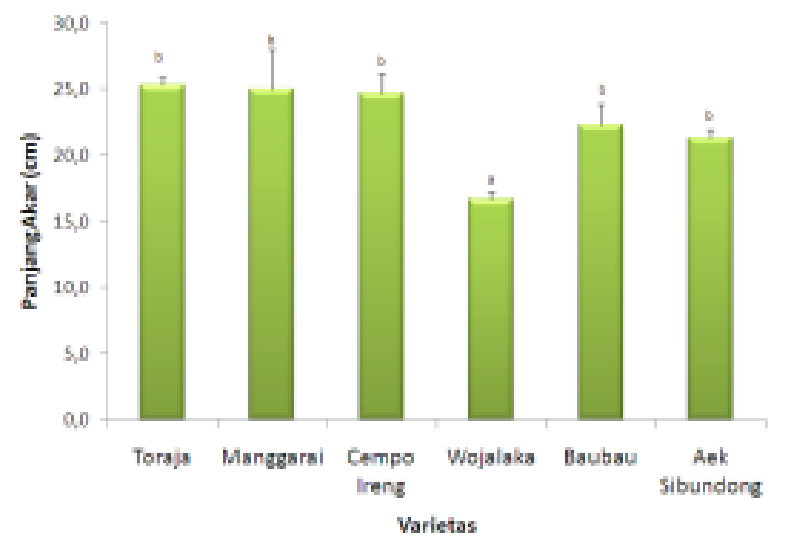

Figure 1. The root length of six pigmented rice varieties. Note: Similar notation of root length did not show a noticeable difference at $\alpha$ of 0.05 based on Anova, followed by HSD Tukey Test.

\section{Stem Surface Colour}

The observation result using the colour chart denoted the difference in colour pigmentation. 
Toraja, Manggarai, Cempo Ireng, and Baubau had the green colour of kiwi green 548, while Aek Sibundong had its stem surface coloured with purple fresco (Figure 2). Stem surface colour was influenced by light intensity that might also regulate the pigment in the epidermis or parenchyma tissues of the stem. Pigment, that determined stem colour, was anthocyanin pigment. The presence of anthocyanin pigment is the reason of the dark colour of the stem, while the absence of anthocyanin pigment causes the light colour of the stem [21].
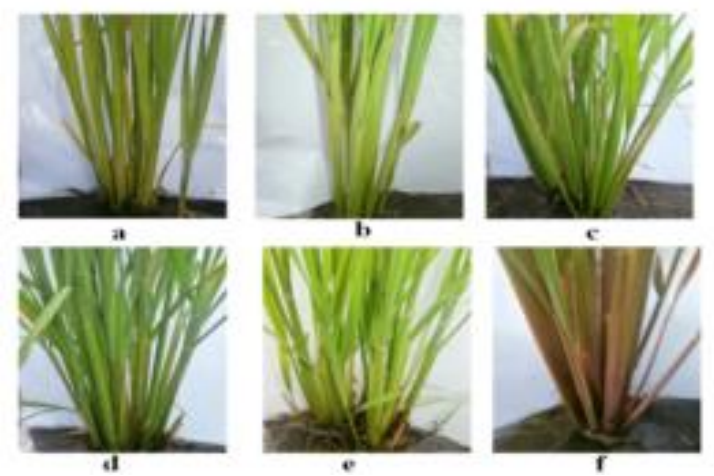

Figure 2. Stem surface colour of pigmented rice: (a) Toraja, (b) Manggarai, (c) Cempo Ireng (d) Wojalaka, (e) Baubau (f) Aek Sibundong

\section{Plant Height}

The plant height was measured in the reproductive stage of flowering because in this stage; the rice did not grow further again. Plant height remained between 99-169 cm. Aek Sibundong had $99 \mathrm{~cm}$ short height, while Wojalaka and Baubau had an average height between 109-112 cm. Cempo Ireng was $138 \mathrm{~cm}$ height, while Manggarai and Toraja had the highest height between 163-169 cm (Figure 3).

In general, farmers expected that the plant did not grow too high because the great height would have a greater possibility of collapse than a shorter one. The resistance against collapse was determined by height, dry weight of straw and panicle, and stem strength. According to Matsushima [22], the weight rate occurs in the stem base is called stem moment or stem index. Stem moment equals to the yield multiplied by plant weight with biomass total (dry weight of straw and panicle). It is measured in gram.cm unit. This statement can be interpreted as higher plant, or greater weight of dry weight of straw and panicle will put greater weight which is held by stem base and, it reduces the resistance to the collapse. Therefore, other varieties approaching the leading capacity of Aek Sibundong are Wojalaka and Baubau.

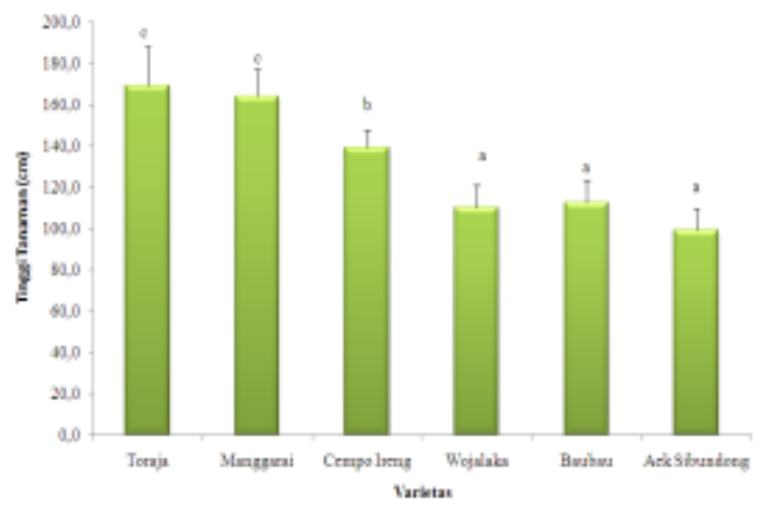

Figure 3. Plant height of six pigmented rice varieties. Note: Similar notation of plant height did not show a noticeable difference at $\alpha$ of 0.05 based on Anova, followed by HSD Tukey Test.

\section{Stem Diameter}

The research result confirmed that the stem diameter of six pigmented rice varieties had a significant difference. Aek Sibundong had 5.6 $\mathrm{mm}$ of small diameter in average. Wojalaka and Baubau had 6.8-7.2 $\mathrm{mm}$ diameter of moderate stem in average. Manggarai and Cempo Ireng had 8.7-9.2 $\mathrm{mm}$ of a big diameter in average. Toraja had bigger diameter of the stem with $9.7 \mathrm{~mm}$ (Figure 4).

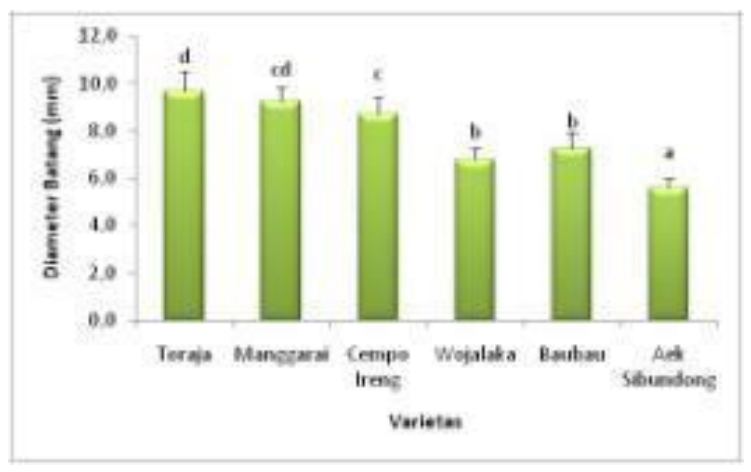

Figure 4. Stem diameter of six pigmented rice varieties. Note: Similar notation of stem diameter did not show a noticeable difference at $\alpha$ of 0.05 based on Anova, followed by HSD Tukey Test.

Stem is functioned as the prop of the plant, as the supplier of chemical compounds and water throughout the plant, and as a food reserve. Sturdy rice stem ensures high plant yield. 
Without the strong stem, plants collapse easily during the strong wind season. Stem diameter is an indicator of mechanic power that influences rice plant's resistance to collapse. It is explained by [23] that plant collapse can reduce plant yield drastically. The collapse begins with the bending or the breaking of two lowest stem knuckles which are more than four $\mathrm{cm}$ length. The strength between stem knuckles is influenced by (a) mechanic strength, namely stem thickness and tissue strength; (b) chemical composition; and (c) dry matter status of plant. The mechanic strength can be increased by giving potassium. The increase also may be due to stem thickening, but it may be useful to keep the turgor pressure of stem cells to remain high. Short and firm stem is the expected character for the development of leading rice varieties because the plant is resistant to collapse; the comparison between grain and straw is well balanced, and the plant is more responsive to nitrogen fertilizer [23, 24].

\section{The Number and Length of Stem Internode}

The stem consisted of some internodes bordered by knuckle, leaf and shoot (seedling) grown on knuckle. Result of research indicated that Manggarai had four internodes; Toraja, Cempo Ireng, and Baubau had five internodes; Wojalaka had more internodes, or six internodes. Aek Sibundong had seven internodes as the most number of all (Figure 5).

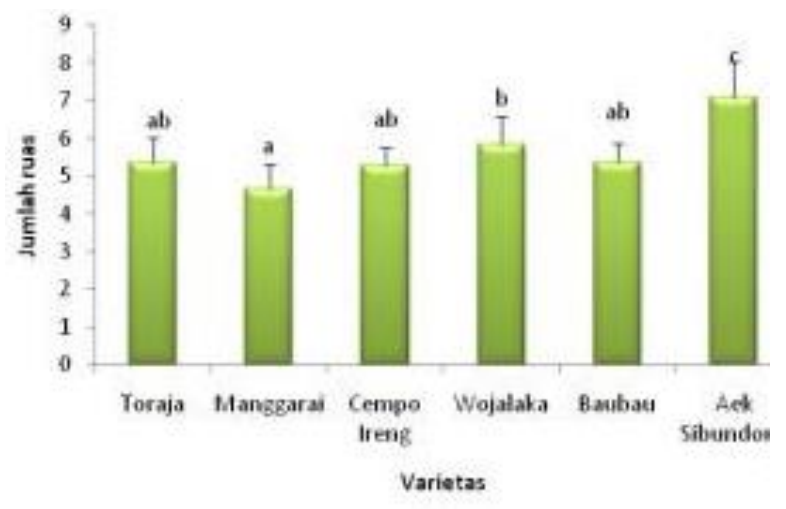

Figure 5. The number of stem internode of six pigmented rice varieties. Note: Similar notation of stem internode did not show a noticeable difference at $\alpha$ of 0.05 based on Anova, followed by HSD Tukey Test.
The number of knuckle and internode equals to the number of leaf plus two, which is one knuckle for coleoptile growth and another knuckle for panicle base [23, 25]. It allows many internodes to present and greater number of leaf to grow on the rice plant. Greater number of internode will make rice plant to be sturdier.

The result revealed that in six pigmented rice varieties, the length of the first internode was short by $4.5-6.8 \mathrm{~cm}$ in average while the topmost internode is standing as panicle base was the longest one ranging from 15.9-47.2 cm (Figure $6)$.

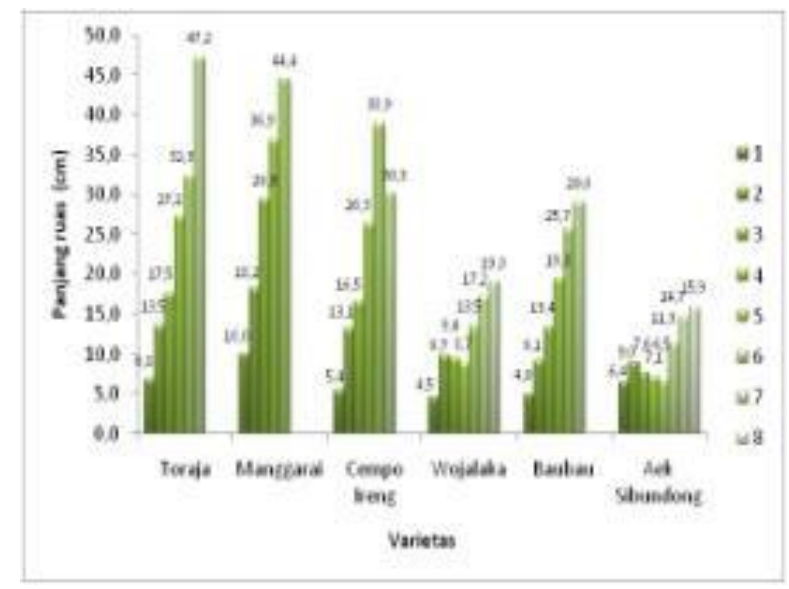

Figure 6. The stem internode length of six pigmented rice varieties

The research result indicated that the internode length was related to the plant height. Higher plant meant longer internode. Toraja, Manggarai and Cempo Ireng were varieties with long internode. Baubau had moderate one, while Wojalaka and Aek Sibundong had short ones. The longest internode was the topmost internode, and the length was declining until the lowest internode nearby land surfaced. The surface of the stem grows stadia comprised of leaf sheaths and solid bulked internodes. The internodes elongated and remained hollow after the plant entered reproductive stadia. Therefore, reproductive stadia are also called as internode elongation stadia $[23,26]$

\section{Character}

Rice leaf grew on the stem by an interval arrangement, in which one leaf was for each knuckle. Each leaf comprised of (i) leaf sheet, (ii) 
leaf sheath covering the internode, (iii) leaf neck (auricle) and (iv) leaf tongue (ligule). The observed morphological characters of leaf were ligule's (leaf tongue) colour and length, sheath color, leaf sheet color, leaf sheet surface, maximum leaf's length and width, trichome's distribution of adaxial and abaxial surfaces of the leaf.

The observation result using the colour chart indicated that ligule colour of pigmented rice had two colour variations namely brownish white 746 and purple orchid 430. Toraja, Manggarai, Wojalaka and Cempo Ireng had similar color, namely brownish white 746, while Aek Sibundong was coloured with purple (orchid 430). The result presented the significant difference of ligule length based on Anova test at $\alpha$ of 0.05 . The ligule length scale, according to [30], are short $(<7 \mathrm{~mm})$, moderate $(7-18 \mathrm{~mm})$, and long $(>18 \mathrm{~mm})$. Manggarai, Wojalaka, and Cempo Ireng had reasonable ligule length which was 14.91-6.9 $\mathrm{mm}$ in average, while Aek Sibundong and Baubau had long ligule length between 20.2-21.0 $\mathrm{mm}$ (Figure 7). The function of ligule is to prevent rain water from entering the stem and leaf sheath. Moreover, ligule also prevents the occurrence of disease infection due to water as a medium of disease distribution [27].

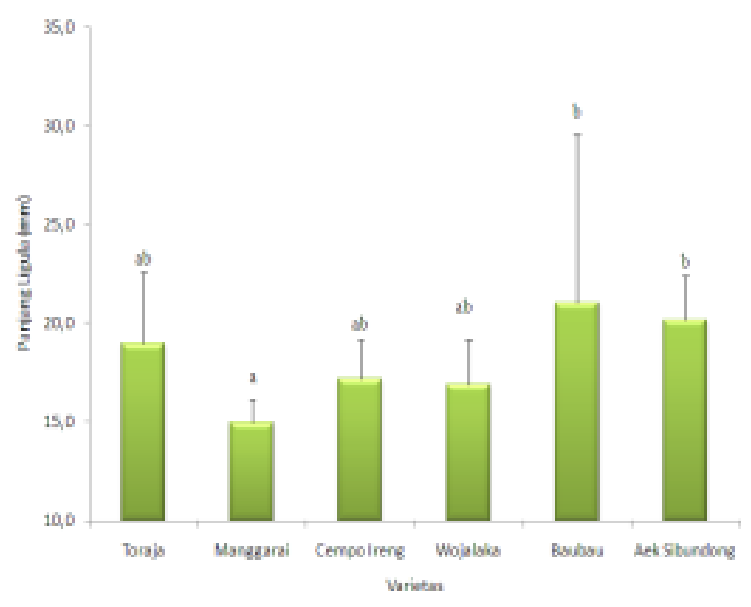

Figure 7. Ligule length of six pigmented rice varieties. Note: Similar notation of ligule length did not show a noticeable difference at $\alpha$ of 0.05 based on Anova, followed by HSD Tukey Test.

The observation result pointed out that the different colour variation was found in the leaf sheet colour based on the colour chart. Leaf colours of Toraja, Manggarai, Wojalaka, Cempo
Ireng and Baubau were similar, namely old green (kiwi green 548), while Aek Sibundong variety's leaf sheet was also coloured by old green but with a purple edge. The result also showed that auricle colour differed with Toraja, Manggarai, and Aek Sibundong varieties whose colours were green (seafoam green 520) while Wojalaka, Cempo Ireng and Baubau were light green (apple green 550). Leaf sheath colour also varied. Toraja and Manggarai Varieties were light green (apple green 550). The leaf sheath colour of Aek Sibundong was an old green (Kiwi green 548) while that of Cempo Ireng and Baubau were bright green (Jasmine green 551).

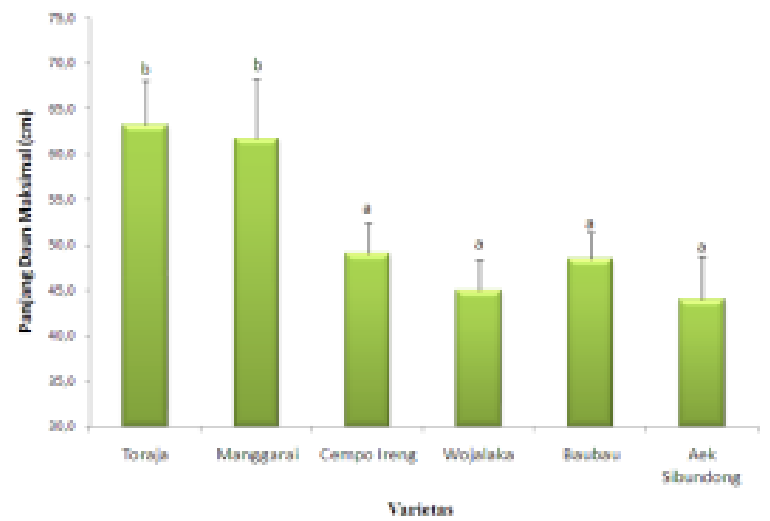

Figure 8. Maximum leaf length of six pigmented rice local varieties. Note: Similar notation of maximum leaf length did not show a noticeable difference at $\alpha$ of 0.05 based on Anova, followed by HSD Tukey Test.

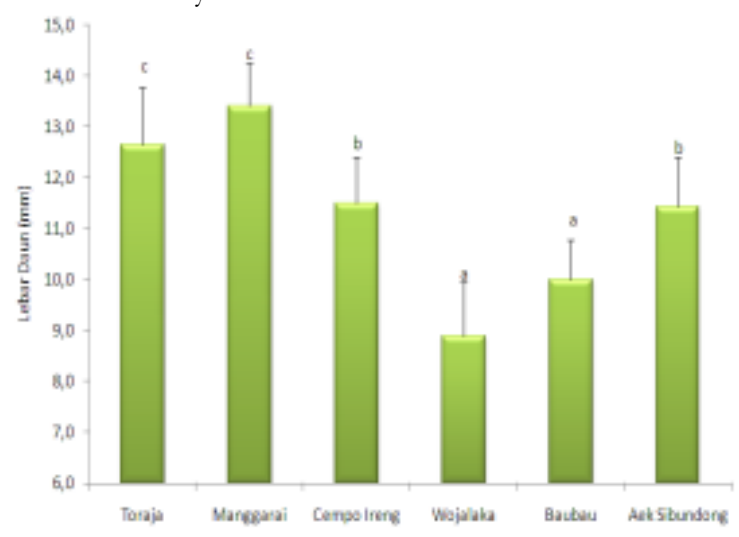

Viritia:

Figure 9. Maximum leaf width of six pigmented rice local varieties. Note: Similar notation of maximum leaf width is not showing obvious difference at $\alpha$ of 0.05 based on Anova, followed by HSD Tukey Test.

The observation on maximum leaf length of six pigmented rice varieties also resulted in a significant difference. Aek Sibundong, Wojalaka, 
Cempo Ireng and Baubau had short leaf that was 43.9-49.0 in average, while Toraja and Manggarai varieties had long leaf that was $61.2-63.2 \mathrm{~cm}$ in average (Figure 8). The observation on maximum leaf width had found a significant difference. Wojalaka and Baubau had the smallest leaf width which was 8.9-10.0 $\mathrm{mm}$ in average. Aek Sibundong and Cempo Ireng had moderate leaf width which was $11.4-11.5 \mathrm{~mm}$ in average, while Toraja and Manggarai had the widest leaf width which was 12.6-13.4 $\mathrm{mm}$ in average (Figure 9).

The character of the leaf is one of morphological characters closely related to plant productivity [33]. [24] considers the leaf as the organ that must be measured for refinement, in terms of its uprightness, length, width, colour and softness. The expected leaf characters are upright growth, thick, small and short. Longer leaf tends to collapse. The short and small leaf is more upright. Indeed, short, small and upright leaf can produce higher photosynthesis rate in every part of the leaf, thus provide the even distribution of leaf in the crown, wider exposure of surface to sunbeam, and even distribution of the beam on leaf [23]. Therefore, varieties included in the plant refinement based on leaf morphology character are Aek Sibundong, Wojalaka, Baubau and Cempo Ireng.

\section{Leaf Surface and Total of Trichome}

Trichome distribution rate on the adaxial surface of the leaf had a significant difference. Cempo Ireng and Toraja had high distribution rate of trichome by $313-402(100 \mathrm{~cm})^{-2}$ in average, while Manggarai, Wojalaka, Baubau and Aek Sibundong had low distribution rate of trichome by average of 7-33 $(100 \mathrm{~cm})^{-2}$ (Figure 10).

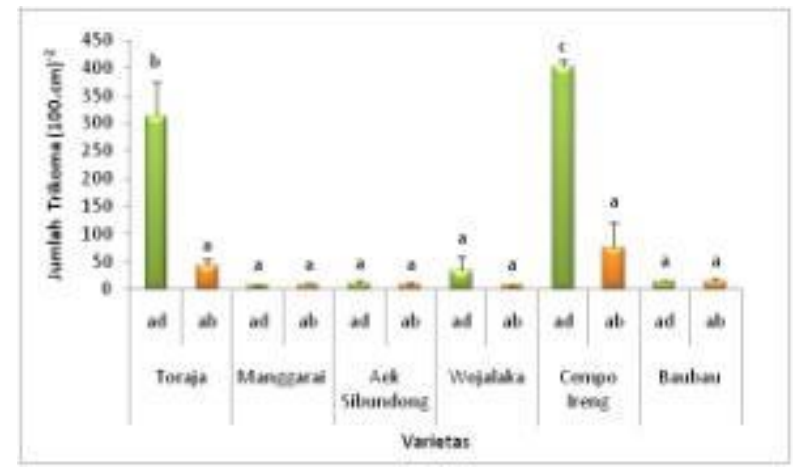

Figure 10. The distribution rate of trichome on adaxial and abaxial surfaces of leaf. Note: $a b=$ abaxial surface, $a d=$ adaxial surface. Similar notation of trichome distribution rate on upper and lower parts of the leaf did not show a noticeable difference at $\alpha$ of 0.05 based on Anova, followed by HSD Tukey Test.

The distribution rate of trichome on abaxial surface did not have a significant difference, and the average rate of trichome was between 7 and $42(100 \mathrm{~cm})^{-2}$ (Figure 10).

Trichome distribution rate was related with a leaf surface. Higher distribution rate of trichome meant softer and denser leaf surface. In contrast, lower distribution rate of trichome meant rougher leaf surface. Cempo Ireng and Toraja had softer leaf surface, while Aek Sibundong, Manggarai, Baubau and Wojalaka had rough leaf surface. Ligule color, leaf sheet colour and leaf surface are characters used by Balitpa (Balai Penelitian Tanaman Padi-Rice Research Agency) to differ the leading rice from others [28].

\section{Length, Width and Angle of Leaflet}

Leaflet was the longest leaf which covers the topmost internode of the stem. Leaflet was located near panicle. The result indicated that the length, width and angle of leaflet had a significant difference. Aek Sibundong, Wojalaka and Cempo Ireng had short leaflet size which was 29.6-33.3 $\mathrm{cm}$ in average. Baubau had $37.7 \mathrm{~cm}$ moderate length of leaflet. Manggarai and Toraja had the longest length which was 48.6-53.1 cm (Figure 11a). The result found a significant difference for leaflet width. Wojalaka Variety had $11.7 \mathrm{~mm}$ of the smallest leaflet width, and followed in ascending order namely Baubau, Aek Sibundong and Cempo Ireng which were $13.6 \mathrm{~mm}, 13.76$ $\mathrm{mm}, \quad 14.5 \mathrm{~mm}$ as the moderate width, respectively. Manggarai and Toraja were the widest leaflet width between 18.20-19.48 mm (Figure 11b).

According to [34], leaflet angle is distinguished into four. They are upright, moderate $( \pm 450)$, flat and collapse types. The research result indicated that the leaflet angle had a significant difference. It was found that Aek Sibundong and Baubau had a leaflet angle at 13.90-14.10, and both had upright angle type. Wojalaka had a leaflet angle at 43.50, thus it was included within the moderate angle type. Cempo Ireng, Manggarai and Toraja had 62.90, 83.60 and 87.80 
leaflet angles which were included within the flat angle type (Figure 11c).

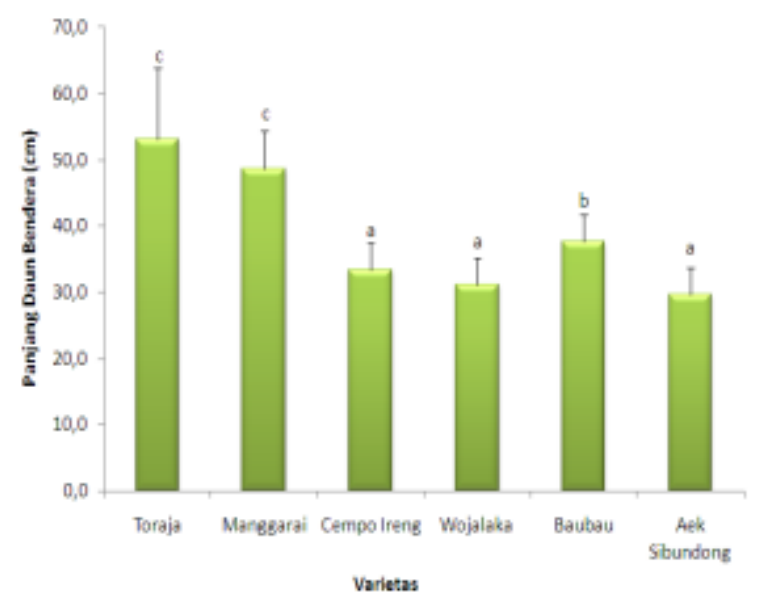

(a)

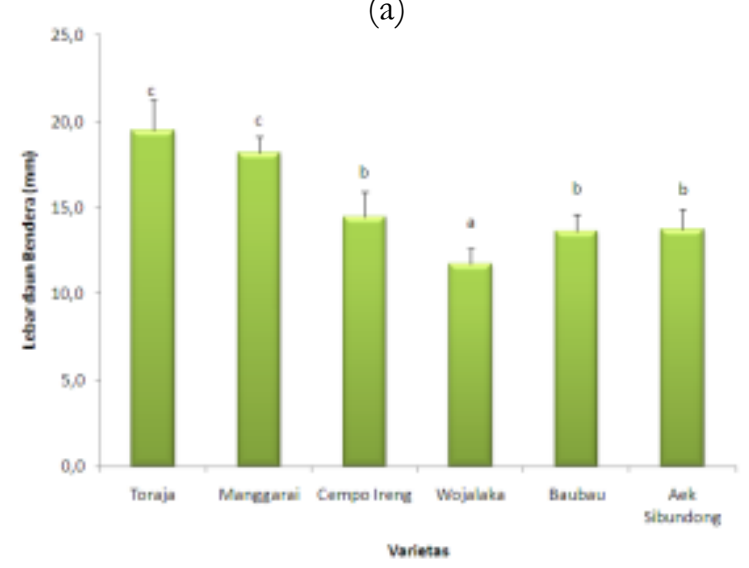

(b)

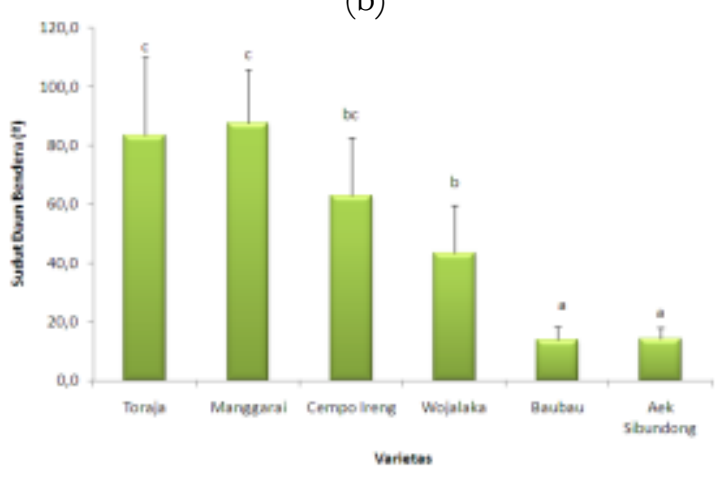

(c)

Figure 11. Length, width and angle of leaflet: (a) Length, (b) Width and (c) Angle of six pigmented rice local varieties. Note: Similar notation of length, width and angle of leaflet did not show a noticeable difference at $\alpha$ of 0.05 based on Anova, followed by HSD Tukey Test.

High assimilation of $\mathrm{CO} 2$ at leaflet will increase the biomass of rice grain [29]. Therefore, longer and wider leaflet would have higher possibility of $\mathrm{CO} 2$ assimilation and produced bigger size or higher number of floret/grain.

In relation to leaflet angle type, the expected leaf characters were leaf with upright growth. Toraja and Manggarai had flat leaf. For the flat leaf, panicle position was not protected by leaflet so that the grain in a panicle was easily attacked by bird.

\section{Floret and Grain}

Each rice flower unit is essential namely floret, which only comprises of one flower [31]. The observation on floret morphology concerned with floret's color, length width, and tail of the distal portion of the floret. The observed grain was milk mature grain and mature grain. The research result indicated that the floret colour was light green (apple green 550) (Figure 12).

The colour of milk mature grain from Wojalaka, Cempo Ireng, Manggarai and Toraja was purplish green (grappa 476), while that of Baubau and Aek Sibundong was yellowish green (pistacio 525). The mature grain of Wojalaka, Cempo Ireng, Manggarai and Toraja was coloured with blackish old purple while that of Baubau and Aek Sibundong was coloured with light yellow (baby maize 625) (Figure 12).

Floret colour is influenced by anthocyanin pigment involving red, purple and black pigments which are contained within pericarp and tegmen (skin layer) of rice, or found in floret part [38]. Rice colour is a distinctive marker benefited by rice variety [32].

The result on the length and width of floret reported a significant difference. Aek Sibundong Variety had $8.45 \mathrm{~mm}$ of short floret size. Manggarai and Baubau had $9.58 \mathrm{~mm}$ of moderate length floret. Cempo Ireng and Toraja had a very long floret length between 9.98 and $9.99 \mathrm{~mm}$ (Figure 13a). Floret width of Baubau was 2.58 $\mathrm{mm}$ considered as a short floret. Aek Sibundong, Wojalaka and Cempo Ireng had moderate floret width between 2.93-3.05 mm. Toraja had 3.33 $\mathrm{mm}$ of wider floret, while Manggarai had the widest floret width which was $3.96 \mathrm{~mm}$ (Figure 13b).

According to Grist [21], three forms of rice grain are estimated based on the ratio of floret's length or width, which are round, moderate and slender. Based on the leading variety used as a 
comparator, Aek Sibundong has a slender floret form [18]. Therefore, based on the observation of the length and width sizes, and on visual observation, Manggarai had round floret, while Toraja, Wojalaka and Cempo Ireng had a moderate floret form, and Baubau had slender floret.

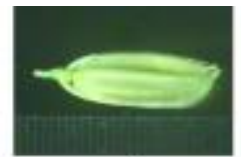

a
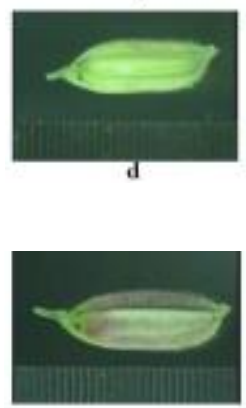

a

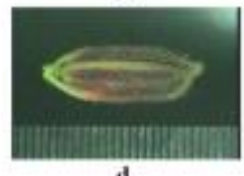

d

a

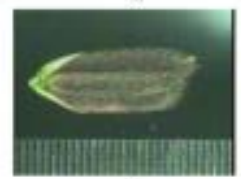

d

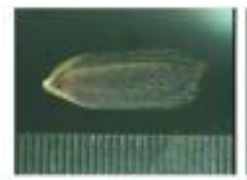

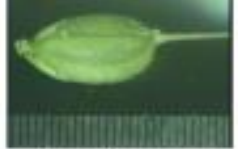

b

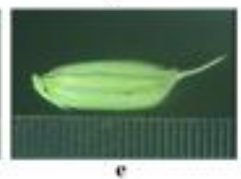

(1)

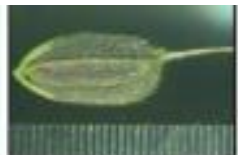

b

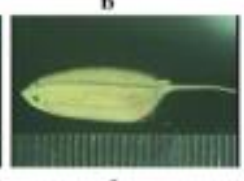

(2)

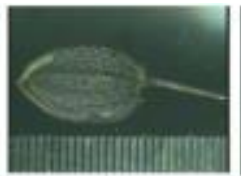

b

(3)

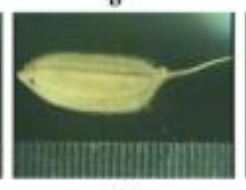

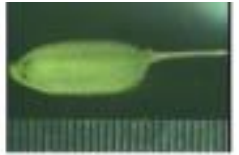

c
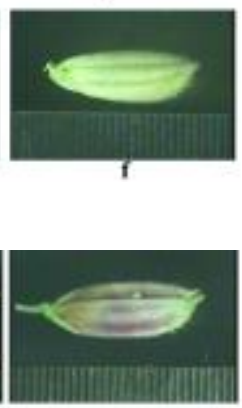

c
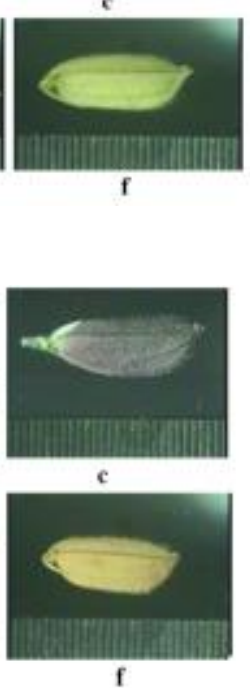

f
Figure 12. The colour of floret, rice grain and the presence of the tail at a distal part of (1) floret, (2) milk mature grain and (3) mature grain of varieties (a) Toraja, (b) Manggarai, (c) Cempo Ireng (d) Wojalaka, (e) Baubau and (f) Aek Sibundong (observed with 6.3x magnification using a stereo microscope). Note: Scale showed $0.5 \mathrm{~mm}$.

The result found the difference for the distal portion of the floret. Manggarai and Baubau had tail at distal portion of the floret until the stage of mature grain. Cempo Ireng had a tail at distal portion of the floret, but during the maturity, it did not (Figure 12). Purbayanti and Irawan [30], have reported that rice cultivar group is divided into two, namely Indica Cultivar Group (cere rice) and Javanica Cultivar Group (rice tricom). Indica cultivar group has some features and among others it is without a tail at distal portion of floret and rice grain. This group is greatly marked by common rice and fast planting age (hawara). The characteristic of Javanica cultivar group is marked by the appearance of the tail at distal part of floret and rice grain, consisting of common rice and glutinous rice, and with a longer planting age (leuir). Based on the appearance of the tail at distal part of the floret and mature grain, the six pigmented rice varieties are divided into two groups. Indica rice group consists of varieties Wojalaka and Aek Sibundong while Javanica rice group comprises of Manggarai, Cempo Ireng and Baubau varieties. Variety Toraja belongs to Javanica due to its longer planting age.

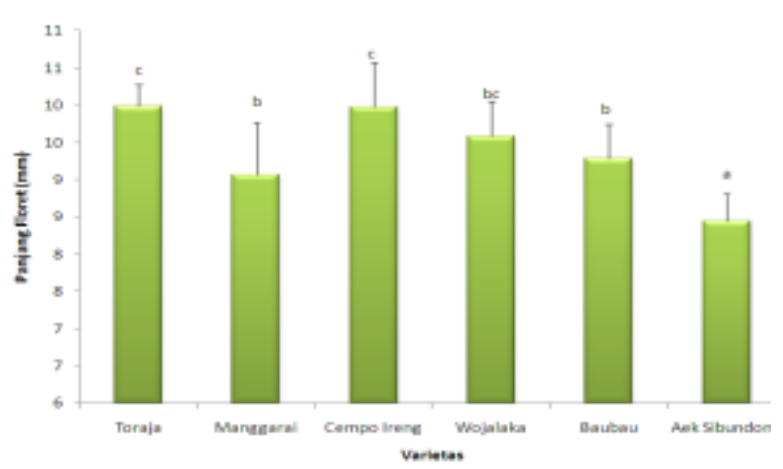

(a)

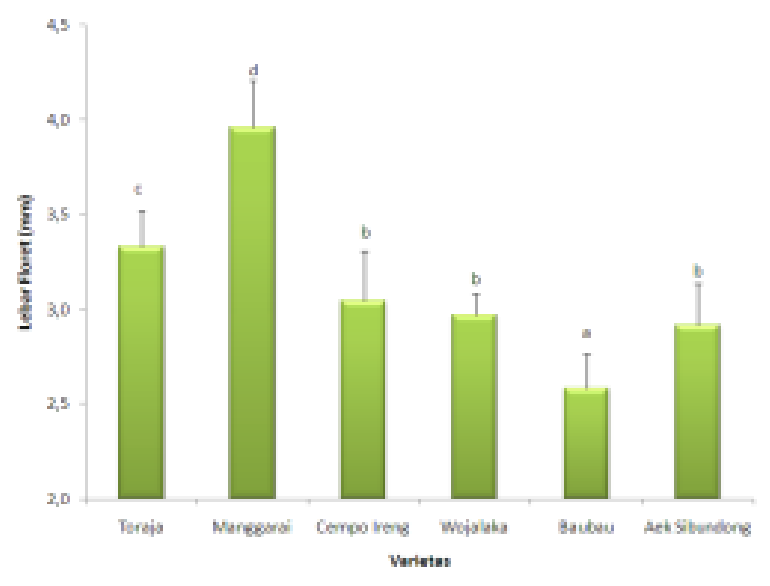

(b)

Figure 13. Length and width of floret: (a) Length and (b) Width of six pigmented rice varieties. Note: Similar notation of length and width of floret did not show an obvious difference at $\alpha$ of 0.05 based on Anova, followed by HSD Tukey Test. 
The observation effect on the panicle tip colour acknowledged that the panicle tip of Cempo Ireng and Wojalaka was coloured with purplish black while the purplish black of panicle tip was not found at other varieties (Figure 14).
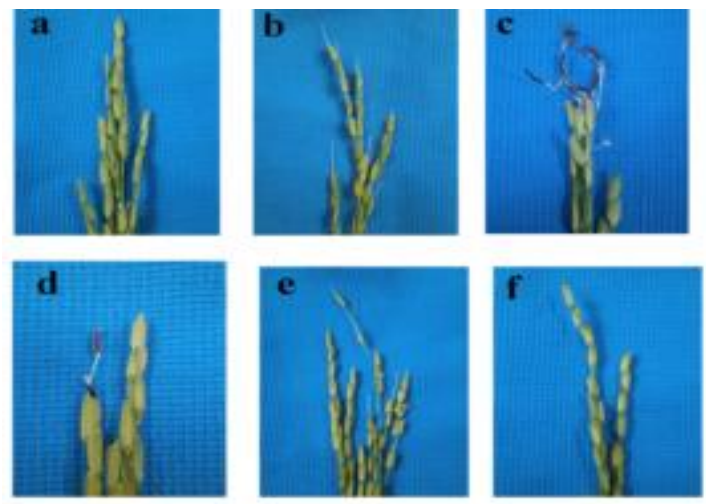

Figure 14. Panicle tip colour of (a) Toraja, (b) Manggarai, (c) Cempo Ireng (d) Wojalaka, (e) Baubau and (f) Aek Sibundong varieties. Note: $\mathrm{c}$ and $\mathrm{d}=$ panicle tip coloured with purplish black.

Based on the result of cluster analysis (Figure 15) and principal component analysis (PCA) over extensive morphologies using biplot (Figure 16), it confirmed that pigmented rice varieties were divided into two groups. The first group included Toraja, Manggarai and Cempo Ireng varieties. The second one involved Aek Sibundong, Baubau and Wojalaka varieties.

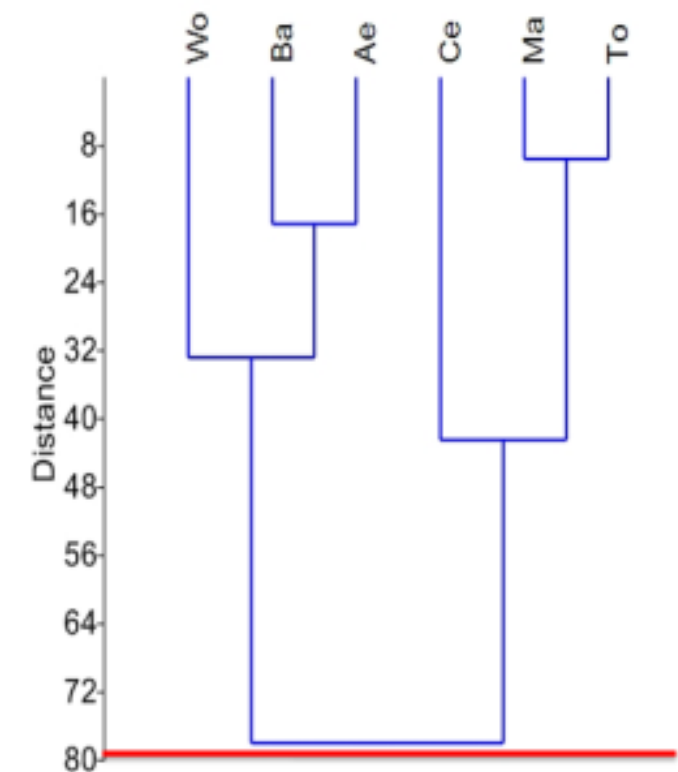

Figure 15. Cluster Analysis on comprehensive morphologies of six pigmented rice varieties. Note $: \mathrm{Ae}=$ Aek Sibundong, $\mathrm{Ba}=$ Baubau, $\mathrm{Ce}=$ Cempo Ireng, $\mathrm{Ma}=$ Manggarai and $\mathrm{To}=$ Toraja.

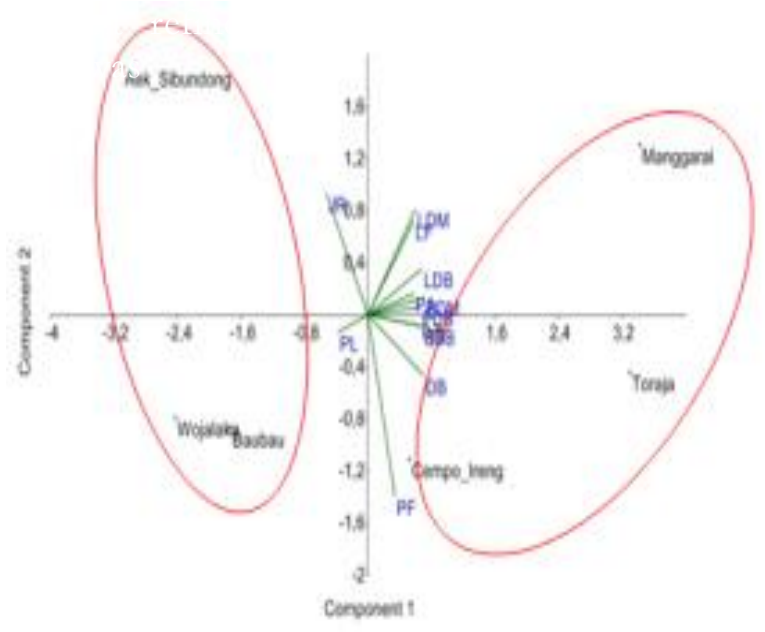

Figure 16. Morphological characters are distinguishing six pigmented rice varieties based on PCA and Biplot Analysis. Note: $\mathrm{JR}=$ number of internode , $\mathrm{LF}=$ floret width, $\mathrm{LDM}=$ maximum leaf width, $\mathrm{LDB}=$ leaflet width, $\mathrm{PDM}=$ maximum leaf length, $\mathrm{PDB}=$ leaflet length, $\mathrm{PL}=$ ligule length, $\mathrm{PF}=$ floret length, $\mathrm{PA}=$ root length, and $\mathrm{SDB}=$ leaflet angle and TT $=$ plant height.

The expected morphological characteristics in the rice plant refinement were enormous. A short plant was expected since it was not easily collapsed. Short, small and upright leaf was also expected morphological characteristic in the rice plant refinement were enormous. A short plant was expected since it was not easily collapsed. Short, small and upright leaf was also expected. Longer leaf tended easily to collapse and cover the lower leaf. Indeed, a short and small leaf is more upright and can produce higher photosynthesis rate in every part of the leaf, thus results in the even distribution of leaf in the crown, wider exposure of surface to sunbeam, and even distribution of the beam on the leaf [23].

\section{CONCLUSIONS}

the six species have two morphological groups, there are Indica rice group consists of Aek Sibundong and Wojalaka, while Javanica rice group involves Toraja, Manggarai, Cempo Ireng and Baubau.

\section{REFERENCES}

1. Chaudhary RC (2003) Speciality rices of the world: Effect of WTO and IPR on its production 
trend \& marketing. Journal of Food, Agriculture and Environment. 1(2): 34-41.

2. Yawadio R, Tanimori S, Morita N (2007) Identification of phenolic compounds isolated from pigmented rices and their aldose reductase inhibitory activities. Food Chemistry. 101(4): 1616-1625.

3. Warta Penelitian \& Pengembangan Pertanian (2005) Padi beras merah: pangan bergizi yang terabaikan. Badan Libang Pertanian Departemen Pertanian. Jakarta.

4. Ryu SN, Park SZ, Ho CT (1998) High performance liquid chromatographic determination of anthocyanin pigments in some varieties of black rice. Journal of Food and Drug Analysis. 6(4): 729-736.

5. Iqbal S, Bhanger MI, Anwar F (2005) Antioxidant properties and components of some commercially available varieties of rice bran in Pakistan. Food Chemistry. 93(2): 265-272.

6. Tabart J, Kevers C, Pincemail J, Defraigne J, Dommes J (2009) Comparative antioxidant capacities of phenolic compounds measured by various tests. Food Chemistry. 113(4): 1226-1233.

7. Chen PN, Kuo WH, Chiang CL, Chiou HL, Hsieh YS, Chu SC (2006) Black rice anthocyanins inhibit cancer cells invasion via repressions of MMPs and u-PA expression. Chemico-Biological Interactions. 163: 218-229.

8. Zawistowski J, Kopec A, Kitts DD (2009) Effects of a black rice extract (Oryza sativa L. indica) on cholesterol levels and plasma lipid parameters in Wistar Kyoto rats. Journal of Functional Foods. 1(1): 50-56.

9. Ahuja U, Ahuja SC, Thakrar R, Singh RK (2008) Rice: a nutraceutical. Asian Agri-History. 12(2): 93108.

10. Frei KB (2004) Improving the nutrient availability in rice-biotechnology or bio-diversity. In: A. Wilake (Ed) Agriculture \& Development Contributing to International Cooperation. 11(2): 64-65.

11. Zhang MW, Guo BJ, Zhang RF, Chi JW, Wei ZC, $\mathrm{Xu}$ ZH, Zhang Y, Tang XJ (2006) Separation, purification and identification of antioxidant compositions in black rice. Agricultural Science in China 5(6): 431-440

12. Chung HS, Shin JC (2007) Characterization of antioxidant alkaloids and phenolic acids from anthocyanin-pigmented rice (Oryza sativa cv. Heugjinjubyeo). Food Chemistry. 104(4): 16701677.

13. Hiemori M., Koh E, Mitchell AE (2009) Influence of Cooking on Anthocyanins in Black Rice (Oryza sativa L. japonica var. SBR). Journal of Agricultural and Food Chemistry. (57): 1908-1914.
14. Kristamtini (2009) Mengenal beras hitam dari Bantul, Tabloid Sinar Tani. Edisi 13 Mei 2009. Indonesia

15. Budiman B, Arisoesiloningsih E, Wibowo EBR (2012) Growth adaptation of two Indonesian black rice origin NT'T cultivating in organic paddy field. Malang. Journal of Tropical Life Science. 2(3).

16. Ishizuka, Y (1969) Engineering for Higher Yields. In: Eastin J.D dkk. (Ed.) Physiological Aspect of Crop Yield. ASA-CSSA. Wisconsin.

17. Loomis RS, Williams WA (1969) Productivity and the morphology of crop stands patterns with leaves. In Physiological Aspects of Crop Yield. ASA-CSSA. Wisconsin.

18. Nafsiah ISD, Sailan M, Rifki A (2006) Aek Sibundong. Kementrian Pertanian Pusat Penyuluhan Pertanian, Badan Penyuluhan dan Pengembangan SDM Pertanian. Pengusul Balai Besar Penelitian Tanaman Padi. Indonesia.

19. Widiarta E (2011) Analisis keberlanjutan praktik pertanian organik di kalangan petani. IPB. Bogor.

20. Hammer, Harper DAT, Ryan PD (2001) PAST: Paleontological statistics software package for education and data analysis. Palaeontologia Electronica.http://palaeoelectronica.org/2001_1 /past/issue1_01. Htm.

21. Grist DH (1986) Rice (Tropical Agriculture Series) Sixth Edition. Longman Inc. London.

22. Matsushima S (1970) Crop Science in rice: theory of yield determination an its aplication. Fuji Publishing. Japan.

23. Yoshida S (1981) Fundamentals of Rice Crop Science. IRRI. Los Banos.

24. Jennings PR (1979) Rice improvement. IRRI. Los Banos.

25. De Datta SK, Vergera BS (1996) Cereals. Prosea Foundation. Bogor.

26. Vergara BS (1980) Rice plant growth and development. In B.S. Luh (Ed.) Rice: Production and Utilization. AVI Publishing Company. Wesport

27. Anonim (1970) Rice Production Manual. Revised Edition. UPCA. Los Banos.

28. Lesmana OS, Toha HM, Las I, Suprihatno B (2004) Deskripsi Varietas Unggul Baru Padi. Sukamandi. Badan Penelitian dan Pengembangan Pertanian, Balai Penelitian Tanaman Padi. Subang.

29. Huqu Z, Shuqing C, Jianmin W, Liangbi L, Tingyun K, Shaokai M, Daefeng Z, Shihua C (2002) Relationship between leaf photosynthetick function at grain filling stage and yield in super high-yielding hybrid rice (Oryza sativa $\mathrm{L}$ ). Science in China. 45(6): 637-646.

30. Purbayanti K, Irawan B (2008) Karakterisasi dan kekerabatan kultivar padi lokal di Desa 
Rancakalong, Kecamatan Rancakalong, Kabupaten Sumedang. Jurusan Biologi Fakultas Matematika dan Ilmu Pengetahuan Alam Universitas Padjadjaran. Bandung.

31. Gould FW (1968) Grass Systematics. McGrawHill Book. New York.

32. Tang S, Wang (2001) Breeding for superior quality aromatic rice varietas in China. In: Speciality Rice's of the Word: Breeding, Production and Marketing. R.C Chaundry, D.V. Tran, R. Duffy (eds) Food Agric Org. Sci. Rome. Inc. Enfield. NH..

33. Makarim KA, Suhartatik E (2009) Morfologi dan fisiologi tanaman padi. Balai Besar Penelitian Tanaman Padi Indonesia

34. Orbani IN, Suprihanto B, Moeljopawiro S (2003) Panduan sistem karakterisasi dan evaluasi tanaman padi. Departemen Pertanian Badan Penelitian dan Pengembangan Pertanian Komisi Nasional Plasma Nutfah.

35. Chang T, Bardenas EA (1965) The morphology and varietal characteristics of the rice plant. The International Rice Research Institute. Manila.

36. Khush GS (1995) Breaking the yield frontier of rice. Geo Journal. 35(3): 329-332.

37. Hirasawa T (1999) Physiological tolerance of water deficits In O. Ito, J.O Toole, and B. Hardy (Eds.) Genetic Improvement of Rice for WaterLimited Environments. IRRI. Los Banos.

38. Chang T, Bardenas EA (1965) The morphology and varietal characteristics of the rice plant. The International Rice Research Institute. Manila. 